\title{
DESAIN OPTIMAL POWER SISTEM STABILIZER PADA UNIT PEMBANGKIT BAKARU BERBASIS ANT COLONY OPTIMIZATION
}

\author{
Muhammad Ruswandi Djalal ${ }^{*}$, Herman Nawir $^{*}$, Sonong $^{*}$, , Marhatang ${ }^{* 4}$ \\ Teknik Pembangkit Energi, Jurusan Teknik Mesin, Politeknik Negeri Ujung Pandang \\ Jl. Perintis Kemerdekaan km.10, Makassar, Indonesia 90245
}

${ }^{*}$ Email : wandi@poliupg.ac.id ${ }^{1}$,herman_nauwir@poliupg.ac.id ${ }^{2}$,sonong@poliupg.ac.id ${ }^{3}$, marhatang@poliupg.ac.id ${ }^{4}$

\begin{abstract}
Abstrak
Salah satu peralatan kontrol tambahan yang mampu meningkatkan kestabilan suatu system pada generator adalah Power System Stabilizer (PSS). Ketika terjadi osilasi gangguan pada generator, PSS memberikan sinyal tambahan ke peralatan eksitasi untuk memberikan redaman tambahan pada generator. Penggunaan PSS diperlukan koordinasi penentuan parameter yang tepat untuk mencapai kontrol kinerja yang bagus untuk sistem. Pada penelitian ini, metode kecerdasan buatan algoritma Ant Colony Optimization (ACO) digunakan untuk mengoptimasi parameter PSS. Dari hasil simulasi didapatkan parameter PSS yang optimal ditinjau dari respon osilasi overshoot dan sudut rotor. Kinerja sistem tanpa PSS didapatkan overshoot frekuensi sebesar -0,02242 s/d 0,005241 pu, kemudian PSS dengan Trial error sebesar -0,0196 s/d $0,003704 \mathrm{pu}$, PSS Bat sebesar $-0.01394 \mathrm{~s} / \mathrm{d} 0.0007533 \mathrm{pu}$, dan dengan metode ant colony didapatkan overshoot yang berkurang yaitu sebesar $-0,0128 \mathrm{~s} / \mathrm{d}$ 0,0003349 pu. Sedangkan untuk respon sudut rotor didapatkan tanpa PSS sebesar 4,71 s/d 4,486e-05 pu, PSS trial error sebesar -4,579 s/d 4,486e-05 pu, PSS Bat sebesar -4.71 s/d 4.486e-05, dan PSS ant colony sebesar $-4,566 \mathrm{~s} / \mathrm{d}$ 4,545e-05 pu. Implementasi metode cerdas sebagai metode penalaan PSS dapat memperbaiki kinerja generator dalam meredam osilasi sistem multimesin.
\end{abstract}

Kata Kunci: Power System Stabilizer, Ant Colony, Eigenvalue, Damping, Settling Time, Overshoot.

\begin{abstract}
One additional control equipment that is able to improve the stability of a system on a generator is the Power System Stabilizer (PSS). When there is a disturbance oscillation on the generator, the PSS provides additional signals to the excitation equipment to provide additional attenuation to the generator. The use of PSS is needed to coordinate the determination of the right parameters to achieve good performance control for the system. In this study, the Ant Colony Optimization (ACO) artificial intelligence method was used to optimize PSS parameters. From the simulation results the optimal PSS parameters are obtained from the overshoot and rotor angle oscillation responses. System performance without PSS obtained frequency overshoot of -0.02242 up to $0.005241 \mathrm{pu}$, then PSS with Trial error of -0.0196 to $0.003704 \mathrm{pu}$, Bat PSS of -0.01394 to $0.0007533 \mathrm{pu}$, and with the ant colony method obtained a reduced overshoot which is equal to -0.0128 to $0.0003349 \mathrm{pu}$. Whereas for the rotor angle response obtained without PSS of -4.71 to 4.486e- 05 pu, the PSS trial error is -4.579 to $4,486 \mathrm{e}-05 \mathrm{pu}$, Bat PSS is -4.71 to $4.486 \mathrm{e}-05$, and ant colony PSS of $-4,566$ to $4,545 \mathrm{e}-05 \mathrm{pu}$. The implementation of the smart method as a PSS tuning method can improve the performance of the generator in reducing the oscillation of the multi-machine system.
\end{abstract}

Keywords: Power System Stabilizer, Ant Colony, Eigenvalue, Damping, Settling Time, Overshoot.

\section{Pendahuluan}

Dalam sebuah penelitian kestabilan dinamik diasumsikan bahwa perubahan torsi akibat respor governor diabaikan karena respon governor sangat lambat dibandingkan dengan respon sistem eksitasi, sehingga pengendali yang berpengaruh adalah sistem eksitasi. Penambahan penguatan rangkaian eksitasi kurang dapat menstabilkan sistem terutama untuk osilasi frekuensi rendah. Osilasi Frekuensi rendah berada antara 0,2 sampai dengan 2,0 Hz [1]. Frekuensi yang lebih rendah dapat semakin meluas menjadi osilasi inter area sehingga diperlukan alat kontrol tambahan berupa Power System Stabilizer (PSS). PSS merupakan alat kontrol tambahan yang berfungsi untuk meredam osilasi frekuensi dan tegangan secara lokal atau global pada generator, sebagai respons dari penyimpangan yang terjadi pada nilai variable yang telah diset [2]. Untuk memperoleh hasil yang maksimal penalaan parameter yang tepat dan optimal pada PSS sangat diperlukan untuk meredam osilasi dan menstabilkan sistem sebagai respon kestabilkan sistem. Penalaan parameter ini dapat menggunakan optimasi metode cerdas, atau biasa disebut kecerdasan buatan. 
Salah satu metode cerdas diadopsi dari perilaku hewan dalam mencari sesuatu.

Ant Colony Optimization (ACO) termasuk dalam kelompok Swarm Intelligence, yang merupakan salah satu jenis pengembangan paradigma yang digunakan untuk menyelesaikan masalah optimasi dimana inspirasi yang digunakan untuk memecahkan masalah tersebut berasal dari perilaku kumpulan atau kawanan serangga [3]. Setiap semut dalam kawanan yang berjalan akan meninggalkan pheromone (semacam zat kimia) pada jalur yang dilaluinya. Feromon ini menjadi semacam sinyal bagi sesama semut. Jalur yang pendek akan menyisakan sinyal yang lebih kuat. Semut berikutnya, pada saat memutuskan jalur mana yang harus dipilih, biasanya akan cenderung memilih untuk mengikuti jalur dengan sinyal yang paling kuat, sehingga jalur terpendek akan ditemui karena lebih banyak semut yang akan melewati jalur tersebut.Semakin banyak semut yang lewat suatu jalur, semakin kuat sinyal di jalur itu. Penggunaan metode ACO juga digunakan pada penelitian ini sebagai metode untuk menala parameter PSS. Penerapan ACO dalam optimasi permasalahan sistem tenaga listrik telah banyak dilakukan, diantaranya manajemen wind generator $[4,5]$, penjadwalan pembangkit [6], kestabilan [7, 8], dan motor listrik [9].

Penalaan parameter yang optimal sangat berpengaruh dalam menstabilkan sistem. Namun range parameter peralatan sangat beragam dan luas, maka untuk memperoleh nilai parameter secara cepat digunakanlah metode optimisasi menggunakan ACO. Nilai respon diketahui dengan menganalisis nilai overshoot dan settling time, sedangkan untuk objective function menggunakan Comperhensive Damping Index (CDI) [10]. Kemudian Menganalisa hasil simulasi dengan cara membandingkan hasil simulasi sistem tanpa PSS, sistem menggunakan PSS, dan sistem menggunakan PSS yang ditala dengan ACO.

Beberapa penelitian penalaan Power System Stabilizer (PSS) dengan menggunakan metode cerdas ACO menunjukkan hasil yang baik dengan beberapa studi kasus pada system Single Machine Infinite Bus (SMIB) [11]. Dari penelitian tersebut penalaan PSS pada SMIB yang tepat dapat memperbaiki osilasi system ketika terjadi perubahan beban [11]. Sistem SMIB merupakan system dengan satu generator. Penerapan metode Ant Colony sebagai metode penalaan PSS dapat dikembangkan lebih jauh pada sistem multimesin, atau suatu system yang memiliki beberapa generator yang terhubung.

Pada penelitian ini penulis mengimplementasikan metode cerdas berbasis ant colony untuk menyelesaikan permasalahan optimasi penentuan parameter PSS pada unit pembangkit bakaru. Unit bakaru merupakan pembangkit yang berkontrobusi bersar pada sistem
Sulselrabar. Unit ini bertindak sebagai generator swing, yang sangat berkontribusi selain menyuplai daya juga sebagai unit yang menjaga kesimbangan system. Begitu bersarnya peran unit pembangkit bakaru, maka diperlukan studi lanjut tentang kemampuan kestabilan sistem, terlebih dinamika beban di sistem Sulselrabar yang semakin berkembang. Pemasangan PSS pada unit bakaru telah dianalisa sebelumnya pada penelitian [12], yaitu dengan menggunakan metode kecerdasan bat algorithm. Dari hasil penelitian tersebut didapatkan kinerja pembangkit yang lebih stabil dengan overshoot minimum dan settling time yang cepat. Kinerja tersebut masih bisa untuk lebih dioptimalkan. Begitu pentingnya peran generator bakaru, maka diperlukan studi lanjut untuk mendapatkan kinerja pembangkit yang lebih baik. Untuk itu pada penelitian ini akan diusulkan suatu metode baru ant colony untuk meningkatkan kinerja dari unit bakaru.

\section{Metode}

Terdapat beberapa langkah pelaksanaan penelitian yang dimulai dengan studi literature, analisis dan kesimpulan, sebagai berikut :

\subsection{Analisis Data}

Studi kasus yang digunakan adalah unit pembangkit bakaru.. Data tersebut kemudian dikelola, beberapa tahapan analisa yaitu, pemodelan system sulselrabar menggunakan simulink, memasukkan data system, studi aliran daya, reduksi jaringan, desain algoritma Ant Colony, dan plotting hasil pemasangan PSS dan dibandingkan dengan PSS trial error dan tanpa menggunakan PSS.

\subsection{Studi Aliran daya}

Pengerjaan Penelitian diawali dengan melakukan simulasi load flow (aliran daya) sistem terlebih dahulu untuk mendapatkan parameter tegangan dan sudut. Hasil dari simulasi ini akan digunakan sebagai data untuk pemodelan linier sistem [13].

\subsection{Pemodelan Sistem}

Pemodelan generator sangat diperlukan untuk menganalisis efek perubahan pada respon frekuensi dan sudut rotor. Dengan menggunakan transformasi park, generator sinkron dapat dimodelkan ke dalam persamaan matematika dan dilinearisasi kedalam persamaan 1 [14]. Variabel-variabel pemodelan diantaranya $V_{d}$ Tegangan stator sumbu d, $V_{F}$ Tegangan medan rotor, $\mathrm{V}_{\mathrm{D}}$ Tegangan kumparan $\mathrm{D}$ rotor, $V_{q}$ Tegangan stator sumbu q, $V_{Q}$ Tegangan kumparan $\mathrm{Q}$ rotor, $r$ resistansi rotor, $L_{d} \& L_{d}$ Induktansi Rotor, $\lambda_{q 0}$ cakupan fluk inisial (sumbu q), $F$ frekuensi listrik, $k M_{F}$ medan magnet berputar, $M_{Q} \& M_{D}$ induktansi bersama, $\lambda_{d 0}$ cakupan fluk inisial (sumbu d), $\Delta i_{d}$ arus stator sumbu $\mathrm{d}, \Delta i_{F}$ arus medan rotor, $\Delta i_{D}$ arus 
kumpaaran $\mathrm{D}$ rotor, $\Delta i_{q}$ arus stator sumbu $\mathrm{q}, \Delta i_{Q}$ arus kumpaaran $\mathrm{Q}$ rotor, $\Delta \omega$ perubahan kecepatan generator, dan $\Delta \delta$ perubahan sudut rotor generator.

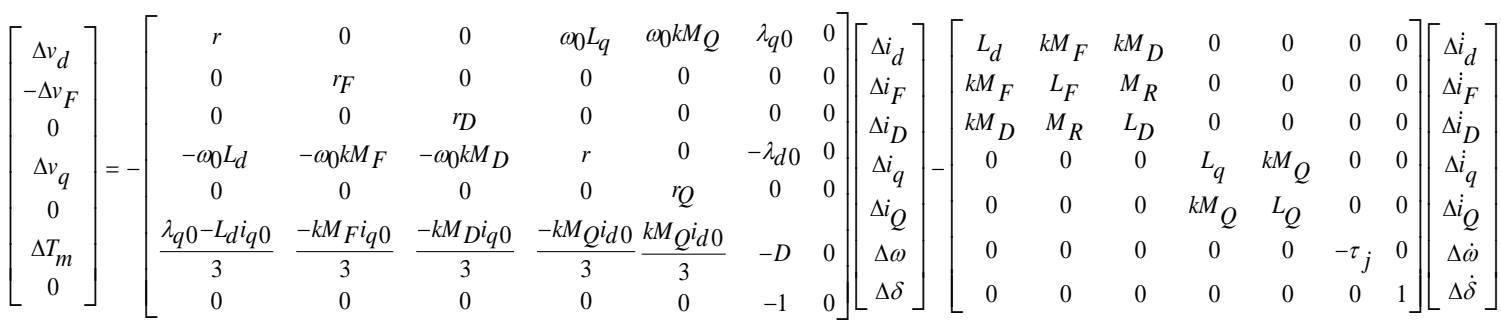

\subsection{Pemodelan Eksitasi}

Peralatan eksitasi adalah salah satu bagian sistem yang di mana dengan eksiter ini dapat mengatur variabel output generator, seperti tegangan, arus dan faktor daya [15]. Gambar 1 berikut untuk pemodelan eksitasi. $\mathrm{K}_{\mathrm{A}}$ parameter penguatan, $\mathrm{T}_{\mathrm{A}}$ konstanta waktu, $\mathrm{V}_{\mathrm{rmax}}, \mathrm{V}_{\mathrm{Rminv}}$ Exciter Output Limiter.

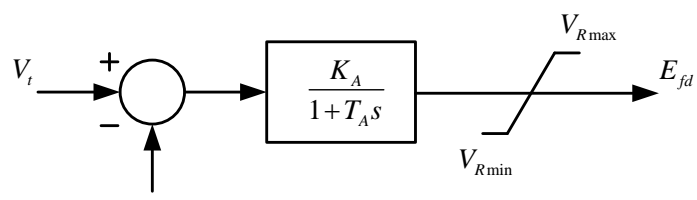

Gambar 1. Block Diagram Eksitasi

\subsection{Pemodelan Governor}

Governor adalah sebuah kontroler yang berfungsi untuk mengatur nilai torsi mekanik Tm yang menjadi input dari generator [15]. Gambar 2 menunjukkan pemodelan governor. $E_{f d}$ output medan, $K_{g}$ konstanta gain, $T_{g}$ Governor Time Constant, $T_{m}$ torsi mekanik dan GSC Governor Speed Changer.

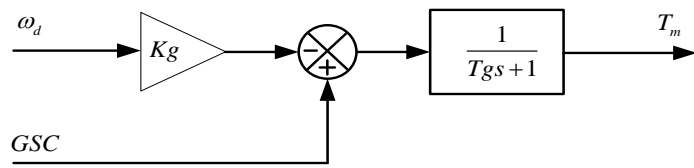

Gambar 2. Pemodelan Governor

\subsection{Power System Stabilizer Modelling}

PSS digunakan sebagai komponen pembangkit damping tambahan yang menghasilkan torsi listrik. Berikut diagram blok dari PSS, di mana parameter Kpss, T1, T2, T3 dan T4 akan dioptimasi oleh metode cerdas ant colony. Gambar 3 berikut adalah pemodelan PSS. KPS, PSS Gain, $\mathrm{T}_{\mathrm{w}}$ Washout Filter, $\mathrm{T}_{\mathrm{A}}, \mathrm{T}_{\mathrm{B}}, \mathrm{T}_{\mathrm{C}}, \mathrm{T}_{\mathrm{D}}$ adalah LeadLag Gain dan $\mathrm{V}_{\text {Smax }} \mathrm{V}_{\text {Smin }}$ limiter.

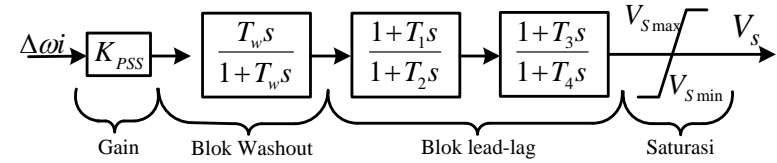

\section{Gambar 3. Block Diagram PSS}

Pemodelan keseluruhan komponen generator ditunjukkan pada gambar 4, dengan pemasangan komponen kontrol PSS. Gambar 5 menunjukkan pemodelan keseluruhan sistem multimesin mulai dari perangkat generator serta transmisi.

\section{Pemodelan Generator Keseluruhan}

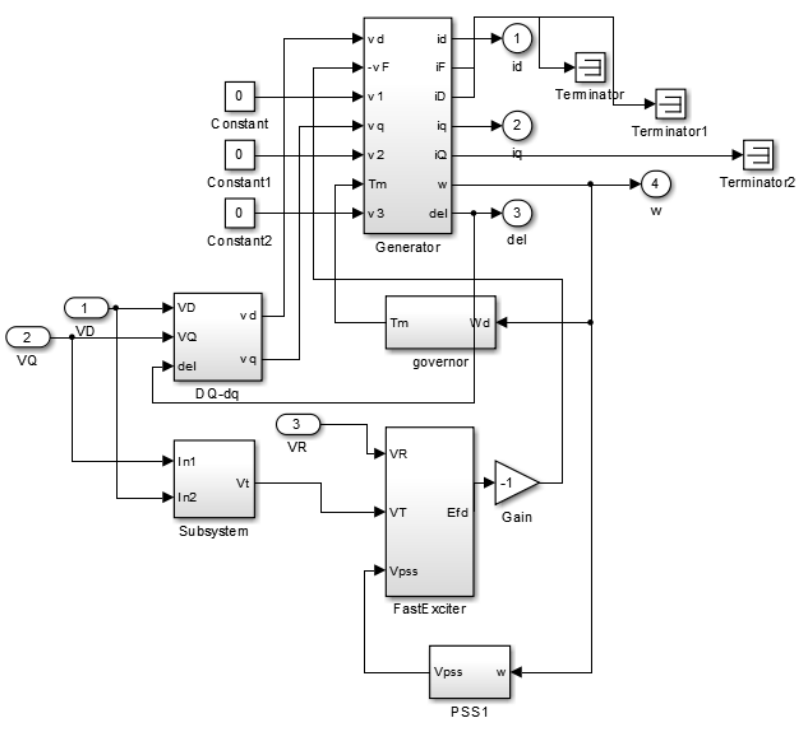

Gambar 4. Pemodelan Generator 

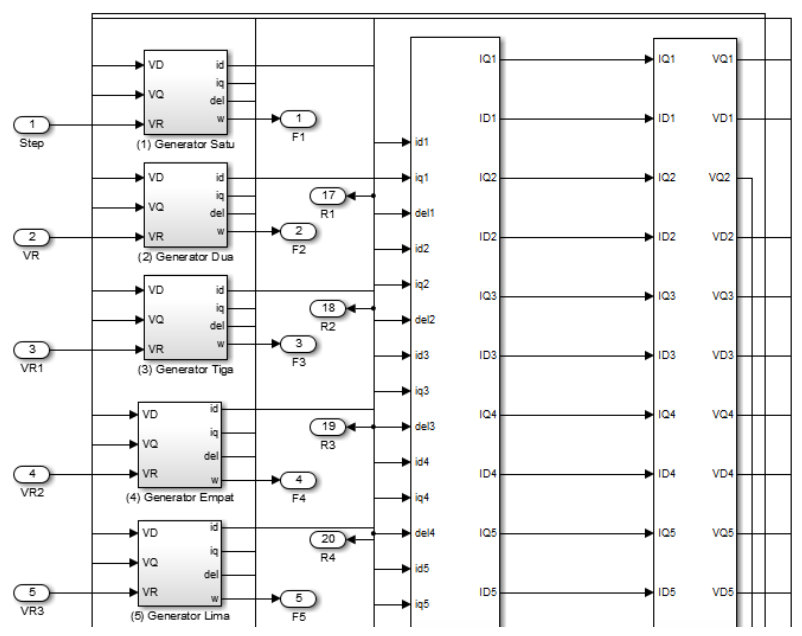

Gambar 5. Pemodelan Sistem di Simulink

\subsection{Ant Colony Optimization}

\section{Penentuan Jarak Antar Kota}

Kota yang dimaksud di sini adalah besarnya nilai pembangkitan dari masing-masing pembangkit. Sebelum dilakukan perjalanan, jarak antara nilai dari pembangkitan pembangkit yang satu dengan pembangkit yang lainnya dihitung terlebih dahulu (diinisialisasi). Setelah dilakukan inisialisasi, maka semut diletakkan di kota pertama tertentu secara acak. Kemudian semut akan melanjutkan perjalanannya dari satu kota ke kota yang lainnya secara acak sampai ke tujuan akhir, yaitu kota terakhir. Setelah perjalanan selesai, lokasi kota-kota yang telah dilalui oleh semut akan digunakan untuk menghitung solusi yang dihasilkan dari perjalanan tersebut .

\section{Perjalanan Semut}

Semut memilih suatu jalur yang akan dilalui mulai dari titik $r$ menuju ke titik $s$ dalam suatu perjalanan dengan probabilitas :

$$
\mathrm{p}(\mathrm{r}, \mathrm{s})=\frac{\gamma(\mathrm{r}, \mathrm{s})}{\sum_{\mathrm{t}} \gamma(\mathrm{r}, \mathrm{l})} \mathrm{s}, 1 \in \mathrm{N}_{\mathrm{r}}^{\mathrm{k}}
$$

matrix $\gamma(\mathrm{r}, \mathrm{s})$ merepresentasikan jumlah intensitas feromon antara titik $r$ dan s. Kemudian feromon akan diperbaharui melalui persamaan berikut :

$$
\gamma(\mathrm{r}, \mathrm{s})=\alpha \cdot \gamma(\mathrm{r}, \mathrm{s})+\Delta \mathrm{y}^{\mathrm{k}}(\mathrm{r}, \mathrm{s})
$$

dimana $\alpha$ dengan interval $0<\alpha<1$ merupakan daya tahan suatu feromon, maka (1- $\alpha)$ merepresentasikan penguapan yang terjadi pada feromon dan $\Delta \gamma^{\mathrm{k}}(\mathrm{r}, \mathrm{s})$ merupakan jumlah feromon yang semut $\mathrm{k}$ jatuhkan pada jalur $(\mathrm{r}, \mathrm{s})$.

\section{Perbaharui Feromon Lokal}

Jejak feromon $(r, s)$ untuk perjalanan terbaik yang telah dilakukan semut (semut yang menghasilkan parameter optimal PSS) akan diperbaharui dengan menggunakan persamaan berikut.

$$
\gamma(\mathrm{r}, \mathrm{s})=\alpha \cdot \gamma(\mathrm{r}, \mathrm{s})+\frac{\mathrm{Q}}{\mathrm{f}_{\text {best }}} \mathrm{r}, \mathrm{s} \in \mathrm{J}_{\text {best }}^{\mathrm{k}}
$$

dengan $Q$ merupakan sebuah konstanta positif yang sangat besar nilainya.

\section{Perbaharui Feromon Global}

Untuk menghindari terjadinya stagnan (suatu situasi dimana semut akan mengikuti jalur yang sama, yang mana akan menghasilkan solusi yang sama), maka kekuatan jejak feromon dibatasi pada interval berikut :

$$
\gamma(\mathrm{r}, \mathrm{s})=\left\{\begin{array}{c}
\tau_{\min } \text { if } \gamma(\mathrm{r}, \mathrm{s}) \leq \tau_{\min } \\
\tau_{\max } \text { if } \gamma(\mathrm{r}, \mathrm{s}) \geq \tau_{\max }
\end{array}\right\}
$$

Batasan atas dan batas bawahnya adalah sebagai berikut :

$$
\begin{aligned}
\tau_{\text {max }} & =\frac{1}{\alpha \cdot f_{\text {best }}} \\
\tau_{\text {min }} & =\frac{\tau_{\text {max }}}{\mathbf{M}^{2}}
\end{aligned}
$$

dengan $M$ adalah jumlah semut yang melakukan perjalanan.

\section{Plot Perjalanan Semut}

Solusi dari perjalanan koloni semut dalam optimasi parameter PSS diplot ke dalam sebuah grafik sampai batas maksimum iterasi.

\section{Plot Perjalanan Terbaik}

Perjalanan dengan solusi terbaik dari koloni semut (parameter optimal PSS) untuk setiap iterasi diplot sampai batas iterasi maksimum.

\section{Flowchart Ant Colony Optimization}

Diagram alir (flowchart) dari metode Ant Colony Optimization yang digunakan untuk mencari parameter optimal PSS ditunjukkan pada gambar 6.

\section{Parameter Ant Colony Optimization}

Beberapa parameter yang digunakan pada metode Ant Colony Optimization pada penelitian ini adalah sebagai berikut:

- Jumlah semut $=10$

- Iterasi maksimum $=50$

- Ketahan feromon(alpha) $=0,9$

\section{Inisialisasi Feromon (Matriks Tau)}

Matriks tau ini memiliki ukuran $\mathrm{n} \times \mathrm{m}$, dengan $\mathrm{n}$ adalah banyaknya kontroler pada sistem, sedangkan $\mathrm{m}$ adalah banyaknya parameter PSS dengan skala 0 sampai 
dengan 1 yang memiliki interval 0,01. Nilai dari matriks ini akan diperbaharui setiap dilakukan perjalanan oleh koloni semut.

\subsection{Penalaan PSS dengan Ant Colony}

Untuk mengamati respon sistem terhadap penggunaan PSS, maka model linier dari sistem dikombinasi dengan model linier PSS dalam sebuah Persamaan state space berikut. Di mana $\Delta x$ merupajan Matriks Keadaan $(n \times 1)$, $\Delta y$ variabel matriks, output $(\mathrm{m} \times 1)$, u variabel input matriks $(\mathrm{r} \times 1)$, A matriks sistem $(\mathrm{n} \times \mathrm{n})$, B input Matriks $(\mathrm{n} \times \mathrm{r})$, matriks pengukuran $(\mathrm{m} \times \mathrm{n})$, D matriks input ke output $(\mathrm{m} \times \mathrm{r}), \lambda_{\mathrm{i}}$ Ith nilai eigen, $\sigma_{\mathrm{i}}$ komponen nyata nilai eigen $\mathrm{i}$-th, $\omega_{\mathrm{i}}$ komponen imajiner nilai eigen, $\zeta$ rasio peredam, $\mathrm{P}_{\mathrm{e}}$ daya listrik, $\mathrm{P}_{\mathrm{m}}$ daya mekanik.

$$
\begin{aligned}
& \Delta \dot{x}=\mathbf{A} \Delta x+\mathbf{B} \Delta u \\
& \Delta y=\mathbf{C} \Delta x+\mathbf{D} \Delta u
\end{aligned}
$$

Dari matriks A diatas, nilai eigenvalue sistem dapat diamati dan memberikan informasi apakah sistem stabil atau tidak. Melalui hasil eigenvalue maka performansi sistem dapat diamati melalui persamaan Comprehensive Damping Index (CDI) yang ditampilkan pada Persamaan berikut.

$$
\begin{aligned}
& \lambda_{i}=\sigma_{i} \pm \frac{ \pm}{\sigma_{i}} j \omega_{i} \\
& \xi_{i}=\frac{\sqrt{\sigma_{i}{ }^{2}+\omega_{i}{ }^{2}}}{C_{i=1}}\left(1-\xi_{i}\right)
\end{aligned}
$$

Metode optimasi ant colony digunakan untuk menala parameter power system stabilizer sehingga menghasilkan nilai CDI minimum dari sistem.

Parameter PSS yang ditala oleh Ant Colony adalah gain Kpss dan T1-T4. Diagram alir proses penalaan parameter PSS dengan menggunakan metode Ant Colony ditunjukkan oleh flowchart pada Gambar 5 dan Gambar 6 menunjukkan pemodelan sistem pada Simulink Matlab 2013, tanpa kontrol, dengan PSS trial error dan PSS Ant Colony.

Untuk menjalankan algoritma Ant Colony dibutuhkan beberapa parameter, yang disebutkan pada Tabel 1 . Algoritma ant colony dibuat menggunakan software Matlab (m.files) dan pemodelan sistem menggunakan Simulink Matlab. Data parameter-parameter ant colony ditunjukkan pada Tabel 1.

Tabel 1. Parameter ant colony

\begin{tabular}{cc}
\hline Parameter & Nilai \\
\hline Jumlah Ants & 50 \\
Iterasi maksimum & 50 \\
Feromon (Alpha) & 0,9 \\
Beta & 2 \\
\hline
\end{tabular}

Setelah memasukkan beberapa parameter tersebut di Tabel 1, maka selanjutnya algoritma ant colony dijalankan untuk optimasi nilai PSS dari kontroler. Nilai yang tepat akan sangat mempengaruhi kinerja respon kestabilan generator yang didesain pada penelitian ini. Algoritma ant colony membutuhkan proses perhitungan sampai menemukan nilai yang optimal. Gambar 7 menunjukkan grafik konvergensi optimasi nilai PSS menggunakan algoritma ant colony. Konvergensi adalah suatu nilai fitness function yang menjabarkan kriteria optimal dari suatu masalah optimasi.

Gambar 7 menunjukkan grafik konvergensi optimasi nilai PSS menggunakan ant colony, di mana berdasarkan grafik terlihat algoritma ant colony tidak membutuhkan waktu yang lama dalam melakukan proses optimasi, hal tersebut terlihat pada iterasi ke-35 algoritma sudah menemukan nilai PSS yang optimal dengan nilai fitness sebesar 75,4095. Sebagai pembanding digunakan metode Bat Algorithm yang parameternya ditunjukkan pada tabel 2 . Untuk hasil selengkapnya optimasi parameter PSS dari masing-masing metode dapat dilihat pada Tabel 3.

Hasil optimasi ant colony didapatkan nilai fitness function sebesar 75,4095, dengan 50 kali iterasi yang konvergen pada iterasi ke-35, nilai nbest merupakan ant colony terbaik, yang di mana diketahui sebagai hasil optimasi parameter PSS, yaitu Kpss dan T1-T4. Tabel 3 menunjukkan nilai hasil optimasi parameter PSS ditala oleh ant colony. Sebagai pembanding digunakan kendali PSS yang ditunning dengan cara trial error atau cobacoba dan metode bat algorithm pada penelitian sebelumnya [12]. Algoritma Ant Colony pada prinsipnya mencari sumber makanan berdasarkan jejak feromon yang kemudian secara berkelompok akan mengikuti jejak yang memiliki feromon yang terbesar. Dengan prinsip ini algoritma akan mencari parameter yang paling optimal untuk diisikan pada parameter PSS, sehingga didapatkan kendali optimal pada generator. 

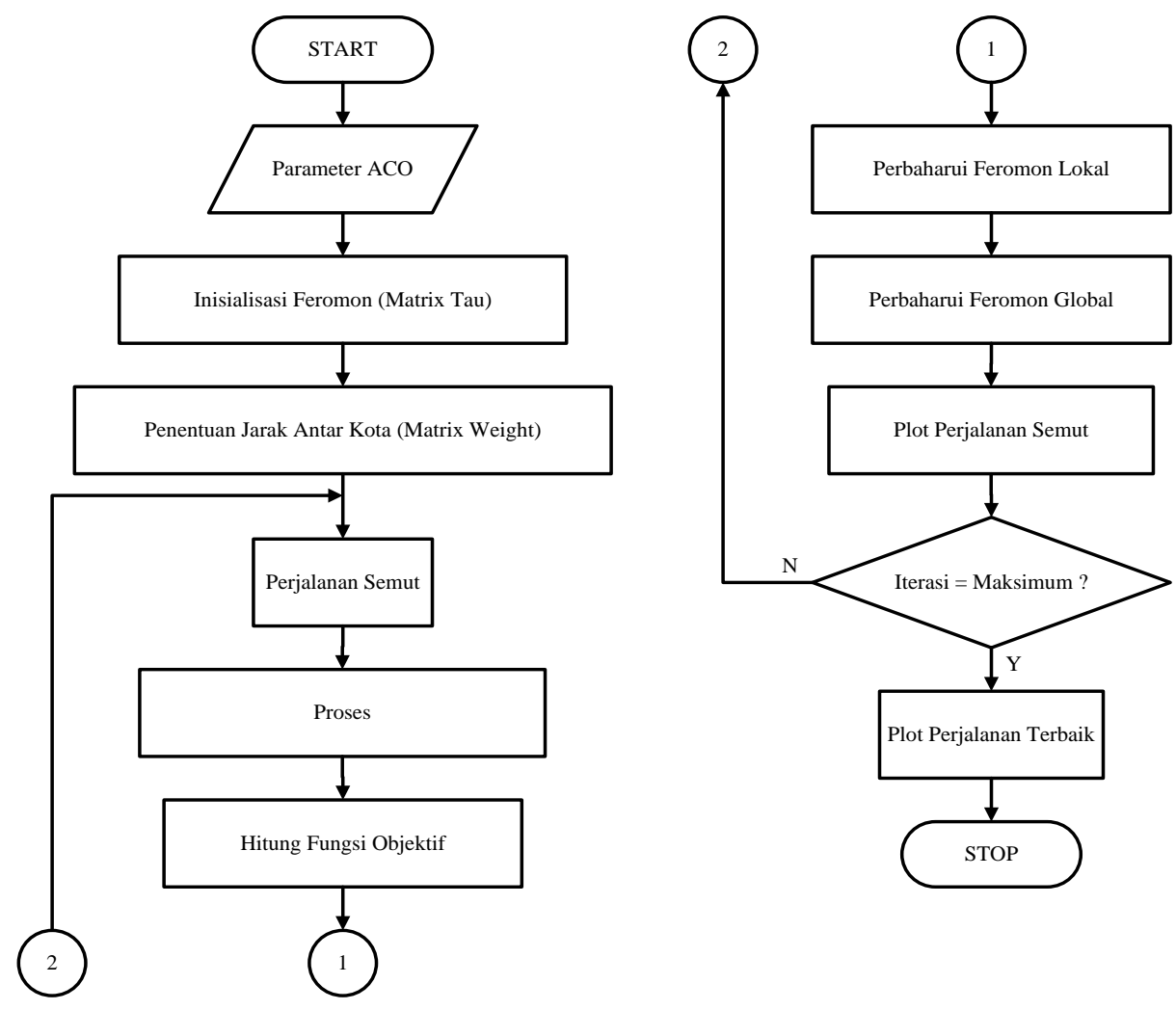

Gambar 6. Flowchart Ant Colony

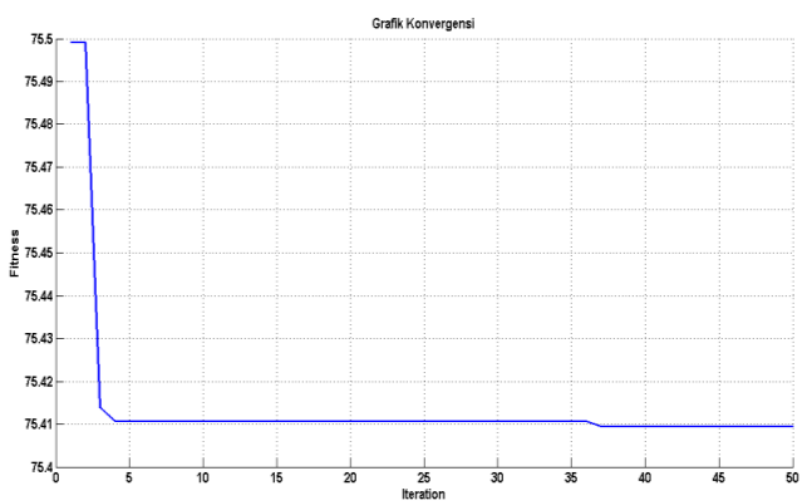

Tabel 3. Hasil Penalaan Power System Stabilizer

\begin{tabular}{cccccc}
\hline Power Plant & Kpss & T1 & T2 & T3 & T4 \\
\hline Trial Error & 48,2272 & 0,0478 & 0,8018 & 0,0493 & 0,8847 \\
Bat & 38.6483 & 0.0243 & 0.0277 & 0.7740 & 1.8598 \\
Ant Colony & 50,9621 & 0,0144 & 0,0317 & 0,0674 & 0,0131 \\
\hline
\end{tabular}

\section{Hasil Simulasi Dan Analisis}

Hasil penalaan parameter PSS ditunjukkan pada Tabel 3, sedangkan sebagai pembanding digunakan PSS yang ditunning dengan metode trial error. Masing-masing yaitu Kpss $=50,9621, \mathrm{~T} 1=0,0144, \mathrm{~T} 2=0,0317, \mathrm{~T} 3=$ 0,0674, dan T4 =0,0131. Sedangkan untuk metode pembanding trial error didapatkan masing-masing Kpss = 48,2272, T1 $=0,0478, \mathrm{~T} 2=0,8018, \mathrm{~T} 3=0,0493$, dan T4 $=0,8847$. Untuk metode bat masing-masing Kpss $=$ $38.6483, \mathrm{~T} 1=0.0243, \mathrm{~T} 1=0.0277, \mathrm{~T} 2=0.7740$, dan $\mathrm{T} 3$ $=1.8598$.

Analisa pertama dimulai dengan meninjau respon kestabilan generator pada unit bakaru tanpa kontrol tambahan. Unit bakaru merupakan pembangkit yang berkontribusi besar pada sistem Sulselrabar. Unit ini bertindak sebagai generator swing, yang sangat berkontribusi selain menyuplai daya juga sebagai unit yang menjaga keseimbangan sistem. Respon generator yang ditinjau adalah kestabilan frekuensi dan sudut rotor. Kemudian dari hasil tersebut dijadikan referensi untuk mendesain kontroler. Analisa berikutnya menggunakan 
PSS yang ditala menggunakan metode trial error, bat dan metode yang diusulkan yaitu menggunakan metode ACO. Hasil simulasi ditunjukkan pada Gambar 8 dan 9.

Dari Gambar 8 dan 9, menunjukkan Deviasi frekuensi dan sudut rotor generator ketika terjadi gangguan dalam hal ini diberi gangguan perubahan beban pada unit generator bakaru, dan dari grafik deviasi frekuensi dapat dilihat besar osilasi overshoot yang terjadi semakin berkurang setelah dipasang PSS, selain itu settling time yang dihasilkan juga akan semakin cepat untuk menuju ke kondisi steady state dengan menggunakan metode yang diusulkan ant colony dibandingkan dengan metode konvensional trial error dan sistem tanpa kontrol. Berikut ditunjukkan respon deviasi system, sedangkan detail overshoot sistem ditunjukkan pada Tabel 4 dan 5 .

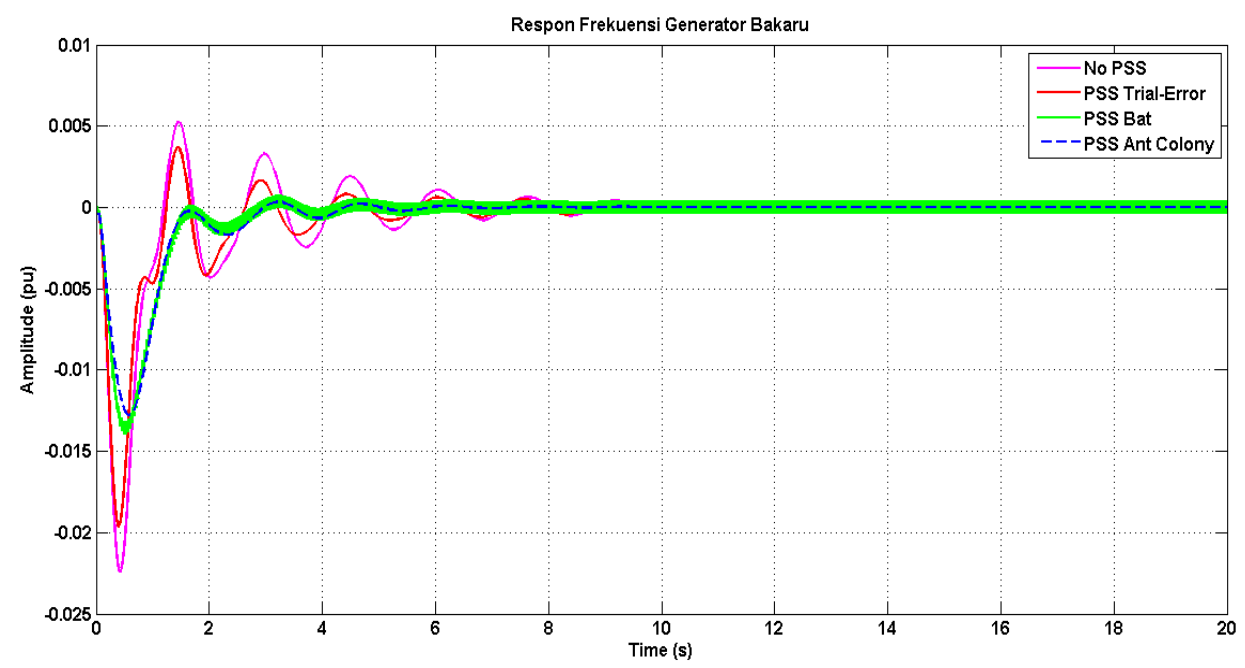

Gambar 8. Respon Frekuensi Unit Pembangkit Bakaru

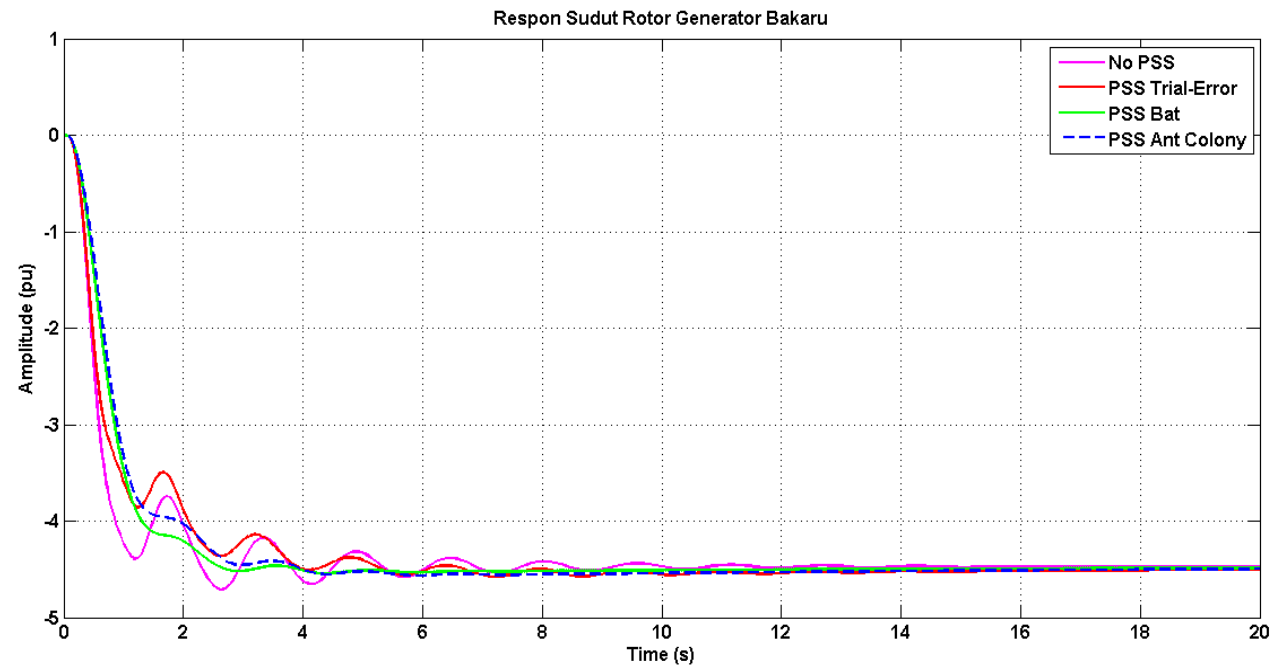

Gambar 9. Respon Sudut Rotor Unit Pembangkit Bakaru

Tabel 4. Osilasi Frekuensi Generator

\begin{tabular}{cccc}
\hline No PSS (pu) & $\begin{array}{c}\text { PSS Trial } \\
\text { Error (pu) }\end{array}$ & $\begin{array}{c}\text { PSS Bat } \\
(\mathbf{p u})\end{array}$ & $\begin{array}{c}\text { PSS Ant } \\
\text { Colony (pu) }\end{array}$ \\
\hline$-0,02242 \mathrm{~s} / \mathrm{d}$ & $-0,0196 \mathrm{~s} / \mathrm{d}$ & -0.01394 & $-0,0128 \mathrm{~s} / \mathrm{d}$ \\
0,005241 & 0,003704 & 0.0007533 & 0,0003349 \\
\hline
\end{tabular}

Tabel 5. Osilasi Sudut Rotor Generator

\begin{tabular}{cccc}
\hline \multirow{2}{*}{ No PSS (pu) } & $\begin{array}{c}\text { PSS Trial } \\
\text { Error (pu) }\end{array}$ & $\begin{array}{c}\text { PSS Bat } \\
(\mathbf{p u})\end{array}$ & $\begin{array}{c}\text { PSS Ant } \\
\text { Colony (pu) }\end{array}$ \\
\hline$-4,71 \mathrm{~s} / \mathrm{d}$ & $-4,579 \mathrm{~s} / \mathrm{d}$ & -4.71 & $-4,566 \mathrm{~s} / \mathrm{d}$ \\
$4,486 \mathrm{e}-05$ & $4,486 \mathrm{e}-05$ & $4.486 \mathrm{e}-05$ & $4,545 \mathrm{e}-05$ \\
\hline
\end{tabular}

Dari Tabel 3, perbandingan nilai overshoot dari masingmasing metode yang digunakan, di mana dengan menggunakan metode yang diusulkan Ant Colony adalah yang paling kecil overshoot yang dihasilkan dan untuk overshoot yang terbesar dihasilkan sistem dengan tanpa PSS. Sebagai misal, untuk sistem tanpa PSS overshoot frekuensi sebesar -0,02242 s/d 0,005241 pu, kemudian PSS dengan Trial error sebesar -0,0196 s/d 0,003704 pu, PSS Bat sebesar -0.01394 s/d 0.0007533 pu, dan dengan metode ant colony didapatkan overshoot yang berkurang yaitu sebesar -0,0128 s/d 0,0003349 pu. Sedangkan untuk 
respon sudut rotor didapatkan tanpa PSS sebesar $-4,71 \mathrm{~s} / \mathrm{d}$ 4,486e-05 pu, PSS trial error sebesar -4,579 s/d 4,486e$05 \mathrm{pu}$, PSS bat sebesar $-4.71 \mathrm{~s} / \mathrm{d} 4.486 \mathrm{e}-05 \mathrm{pu}$. dan PSS ant colony sebesar $-4,566 \mathrm{~s} / \mathrm{d} 4,545 \mathrm{e}-05 \mathrm{pu}$.

Untuk analisa respon perubahan frekuensi, perubahan beban yang terjadi menyebabkan Pe > Pm sehingga dari grafik untuk studi kasus yang digunakan, respon pertama kecepatan generator adalah kebawah. Sedangkan untuk respon sudut rotor, karena $\mathrm{Pe}>\mathrm{Pm}$, maka rotor akan mengalami perlambatan sehingga respon sudut rotor menjadi negatif.

Dari hasil analisis berdasarkan studffffi kasus yang digunakan, didapatkan performansi kinerja sistem yang meningkat dengan pemasangan dan penalaan yang tepat dari Power System Stabilizer pada unit pembangkit bakaru. Sehingga secara keseluruhan sistem dapat meningkatkan keandalan ketika terjadi dinamika perubahan beban.

Fungsi tujuan (Objective Function) yang digunakan pada penelitian ini adalah memaksimalkan damping minimum $\left(\zeta_{\min }\right)$ dari pemasangan PSS. Setelah pemasangan PSS, nilai minimum damping minimum akan dievaluasi oleh metode cerdas yang diusulkan menggunakan Ant Colony. Dengan penalaan yang tepat dari parameter PSS, didapatkan nilai maksimum $\zeta_{\min }$ yang lebih besar dari $\zeta_{0}$. Pemodelan linier sistem diberikan input gangguan perubahan permintaan beban sebesar $0.05 \mathrm{pu}$ pada Generator Slack PLTA Bakaru. Karena perubahan beban ini, mengakibatkan perubahan di sisi beban menyebabkan $\mathrm{P}_{\mathrm{m}}<\mathrm{P}_{\mathrm{e}}$, sehingga $\omega$ generator akan turun.

$$
M \dot{W}=P_{m}-P_{e}-D \omega
$$

Aplikasi metode cerdas pada implementasinya di sistem tenaga memberikan hasil yang baik. Pada penelitian ini diterapkan metode cerdas berbasis kecerdasan semut dalam mencari sumber makanan, dan mampu menghasilkan parameter yang optimal. Selain penerapan kontroler tambahan Power System Stabilizer pada eksitasi, juga dapat ditambahkan kontroler lain untuk menunjang kinerja dari kestabilan generator.

\section{Kesimpulan}

Dari hasil simulasi didapatkan parameter PSS yang optimal dengan penalaan berbasis ant colony yaitu untuk Kpss $=50,9621, \mathrm{~T} 1=0,0144, \mathrm{~T} 2=0,0317, \mathrm{~T} 3=0,0674$, dan $\mathrm{T} 4=0,0131$. Dengan penalaan optimal didapatkan kinerja yang optimal, dimana ditunjukkan dengan overshoot frekuensi dan sudut rotor yang dihasilkan minimum, di mana untuk sistem tanpa PSS overshoot frekuensi sebesar $-0,02242 \mathrm{~s} / \mathrm{d}$ 0,005241 pu, kemudian PSS dengan Trial error sebesar -0,0196 s/d 0,003704 pu, PSS Bat sebesar -0.01394 s/d 0.0007533 pu, dan dengan metode ant colony didapatkan overshoot yang berkurang yaitu sebesar -0,0128 s/d 0,0003349 pu. Sedangkan untuk respon sudut rotor didapatkan tanpa PSS sebesar -4,71 s/d 4,486e-05 pu, PSS trial error sebesar -4,579 s/d 4,486e$05 \mathrm{pu}$, PSS bat sebesar $-4.71 \mathrm{~s} / \mathrm{d}$ 4.486e-05 pu, dan PSS ant colony sebesar $-4,566 \mathrm{~s} / \mathrm{d}$ 4,545e-05 pu. Dengan demikian, implementasi metode cerdas sebagai metode penalaan PSS dapat memperbaiki kinerja generator dalam meredam osilasi sistem multimesin.

\section{Referensi}

[1]. P. Kundur, Power system stability and control vol. 7. McGraw-Hill, 1994

[2]. M. R. Djalal, A. Imran, and I. Robandi, "Optimal placement and tuning power system stabilizer using Participation Factor and Imperialist Competitive Algorithm in $150 \mathrm{kV}$ South of Sulawesi system," in International Seminar on,Intelligent Technology and Its Applications (ISITIA), 2015, pp. 147-152.

[3]. Q. Aliklas, N. Satyahadewi, and H. Perdana, "PENERAPAN ALGORITMA MAX-MIN ANT SYSTEM DALAM PENYUSUNAN JADWAL MATA KULIAH DI JURUSAN MATEMATIKA FMIPA UNTAN," Buletin Ilmiah Math. Stat. dan Terapannya (Bimaster), Volume 8, No. 2, hal 273 - 280, 2019

[4]. M. Carrillo, J. Del Ser, M. N. Bilbao, C. Perfecto, and D. Camacho, "Wind power production forecasting using ant colony optimization and extreme learning machines," in International Symposium on Intelligent and Distributed Computing, 2017, pp. 175-184.

[5]. A. Esmat, A. Magdy, W. ElKhattam, and A. M. ElBakly, "A novel energy management system using ant colony optimization for micro-grids," in 2013 3rd International Conference on Electric Power and Energy Conversion Systems, 2013, pp. 1-6.

[6]. R. Banos, F. Manzano-Agugliaro, F. Montoya, C. Gil, A. Alcayde, and J. Gómez, "Optimization methods applied to renewable and sustainable energy: A review," Renewable and sustainable energy reviews, vol. 15, pp. 1753-1766, 2011.

[7]. P. Lin, X. Liu, H.-X. Chen, and J. Kim, "Ant colony optimization analysis on overall stability of high arch dam basis of field monitoring," The Scientific World Journal, Article ID 483243, 2014.

[8]. W. Gao, "Premium-penalty ant colony optimization and its application in slope stability analysis," Applied Soft Computing, vol. 43, pp. 480-488, 2016.

[9]. D. Sandoval, I. Soto, and P. Adasme, "Control of direct current motor using Ant Colony optimization," in 2015 CHILEAN Conference on Electrical, Electronics Engineering, Information and Communication Technologies (CHILECON), 2015, pp. 79-82.

[10]. M. R. Djalal, H. Setiadi, D. Lastomo, and M. Y. Yunus, "Modal Analysis and Stability Enhancement of $150 \mathrm{kV}$ Sulselrabar Electrical System using PSS and RFB based on Cuckoo Search Algorithm," International Journal on Electrical Engineering and Informatics, vol. 9, pp. 800812, 2017.

[11]. M. A. Joodi, N. H. Abbas, and A.-M. Ruba, "Optimum Design of Power System Stabilizer based on Improved Ant Colony Optimization Algorithm," Journal of Engineering, vol. 24, pp. 123-145, 2018. 
[12]. M. R. Djalal, M. Y. Yunus, H. Nawir, and A. Imran, "Optimal Design of Power System Stabilizer In Bakaru Power Plant Using Bat Algorithm," JEEE-U (Journal of Electrical and Electronic Engineering-UMSIDA), vol. 1, no. 2, hal. 40-44, 2017.

[13]. H. Saadat, Power System Analysis: McGraw-Hill, 2009.

[14]. I. Robandi, Modern Power System Control, Penerbit ANDI, Yogyakarta, 2009.
[15]. M. Y. Yunus, M. R. Djalal, and Marhatang, "Optimal Design Power System Stabilizer Using Firefly Algorithm in Interconnected $150 \mathrm{kV}$ Sulselrabar System, Indonesia," International Review of Electrical Engineering (IREE), vol. 12, pp. 250-259, 2017.

[16]. Suharto, "PENALAAN POWER SYSTEM STABILIZER (PSS) UNTUK PERBAIKAN STABILITAS DINAMIK PADA SISTEM TENAGA LISTRIK MENGGUNAKAN BAT ALGORITHM (BA)," Tugas Akhir, ITS Surabaya, 2015. 